DOI: $10.37190 /$ epe 170203

\author{
JEREMI NAUMCZYK ${ }^{1}$, PIOTR MARCINOWSKI ${ }^{1}$, J. BOGACKI ${ }^{1}$
}

\title{
TREATMENT OF HIGHLY POLLUTED COSMETIC WASTEWATER
}

\begin{abstract}
Three samples of cosmetic wastewater from the production of soaps and shampoos were treated by the following processes: coagulation with sedimentation $(\mathrm{C} / \mathrm{S})$, coagulation with dissolved air flotation $(\mathrm{C} / \mathrm{DAF})$, and the Fenton process $(\mathrm{FP})$. The COD values of raw wastewater samples were 13160 , 13580 and $9410 \mathrm{mg} \mathrm{O}_{2} / \mathrm{dm}^{3}$. The anionic surfactants were 3000,4500 and $4000 \mathrm{mg} / \mathrm{dm}^{3}$, for samples 1,2 , and 3 , respectively. All three processes were effective in highly polluted cosmetic wastewater treatment. The most effective process was coagulation. In the case of sample 1, application of $\mathrm{FeCl}_{3}$ at pH 6.0 resulted in $88.2 \%$ of COD removal and the application of aluminum based coagulants allowed for $80.1-85.3 \%$ COD removal. In the case of samples 2 and 3, the usage of Al 1019 and Al 3010 coagulants brought about a $91.6 \%$ and $82.6 \%$ decrease in COD values, respectively. C/DAF was found to be less effective than $\mathrm{C} / \mathrm{S}$. The best results with $\mathrm{C} / \mathrm{DAF}$ were obtained using Al 3010 coagulant with wastewater recirculation the COD removal efficiency amounted to $82.3,87.3$ and 78.8 , respectively. The lowest COD removal efficiency was observed for FP and it was equal to 64.0 and $72.7 \%$ for samples 2 and 3, respectively.
\end{abstract}

\section{INTRODUCTION}

Cosmetic wastewater is produced during the process of washing of fillers, pallets and other elements of the production line by means of water solution of detergents and disinfectants. Significant differences in the composition and concentrations of contaminants in wastewater depend on the quantity and range of produced cosmetics, which in turn, depends on the season. The bigger the production plant and the broader the range of manufactured personal care products (cosmetics), the more representative sample of wastewater for the cosmetic industry may be obtained.

${ }^{1}$ Warsaw University of Technology, Faculty of Building Services, Hydro and Environmental Engineering, ul. Nowowiejska 20, 00-653 Warsaw, Poland, corresponding author J. Naumczyk, e-mail: jeremi.naumczyk@is.pw.edu.pl 
One of the least expensive and therefore most commonly used methods is biological treatment [1]. The limited efficiency of biological treatment results in the great changeability of the wastewater in time, as well as the presence of significant amounts of compounds resistant to biodegradation (described as $K_{o w}, \mathrm{p} K_{a}, D_{o w}$ ) [2]. In biological wastewater treatment plants, cosmetic compounds are removed mainly through adsorption of activated sludge [2]. On the other hand, both biological and chemical processes result in a large amount of sludge production.

Due to the increased leg $\mathrm{Al}$ requirements concerning the parameters of treated wastewater, new low-cost methods that meet the new requirements are being explored. Other methods such as physicochemical and chemical methods as coagulation [3-9], dissolved air flotation [4], electrocoagulation $[5,10]$ and advanced oxidation processes (AOP) $[6,8,10-14]$ have been employed. Advanced methods based on biological processes such as using membrane reactors $[17,18]$, mixed anaerobic-aerobic processes [19] or anaerobic reactors have also been investigated [20].

Naumczyk et al. [8] used coagulation with an optimal dose of $0.75 \mathrm{~cm}^{3} / \mathrm{dm}^{3}$ of prehydrolyzed ferric coagulant F3 Brentafloc at pH 6 to receive rather low, 37\% COD removal. El-Gohary et al. [4]. achieved a $77.5 \%$, COD removal by coagulation process. The differences in treatment effect are due to differences in the composition of treated wastewater and the type of coagulant [4-9]. El-Gohary et al. [4] demonstrated no significant differences in the effectiveness of coagulation with sedimentation $(\mathrm{C} / \mathrm{S})$ and coagulation with dissolved air flotation (C/DAF). However, the investment and operating costs of $\mathrm{C} / \mathrm{S}$ application are higher by 27.3 and $23.7 \%$, respectively, compared to the $\mathrm{C} / \mathrm{DAF}$ costs [4]. Electrocoagulation results in 78.1 and $82 \%$ of COD removal at the current density of 2.5 and $7.63 \mathrm{~A} / \mathrm{dm}^{2}$, respectively [5,10]. At lower current densities, significantly worse results were obtained. The use of AOP can be effective, also in enhancing of wastewater biodegradability. The best results (over 95\% COD removal) were obtained by the photo-Fenton process (high-pressure lamp TQ $150 \mathrm{~W}, \mathrm{pH} 3,1 \mathrm{~cm}^{3} / \mathrm{dm}^{3}$ of $\mathrm{H}_{2} \mathrm{O}_{2}, 750 \mathrm{mg} / \mathrm{dm}^{3}$ of $\mathrm{Fe}^{2+}, t=40 \mathrm{~min}$ ) and photocatalytic $\mathrm{UV} / \mathrm{TiO}_{2} / \mathrm{H}_{2} \mathrm{O}_{2}$ process (low-pressure mercury lamp $250 \mathrm{~W}, \mathrm{pH} 3,500 \mathrm{mg} / \mathrm{dm}^{3}$ of $\mathrm{TiO}_{2}, 10 \mathrm{mmol} / \mathrm{dm}^{3}$ of $\mathrm{H}_{2} \mathrm{O}_{2}$, $t=3 \mathrm{~h})[10,16]$. The lowest results were found by applying $\mathrm{UV} / \mathrm{H}_{2} \mathrm{O}_{2}$ process $[8,15]$.

The aim of this study was to investigate the efficiency and determination of the optimal conditions for the treatment of cosmetic wastewater by the $\mathrm{C} / \mathrm{S}, \mathrm{C} / \mathrm{DAF}$, and FP. The decrease in the contaminants content should enable the wastewater disposal to a municipal sewage system and further treatment in a biological wastewater treatment plant.

\section{MATERIALS AND METHODS}

Three samples of wastewater were collected from an equalizing tank at a cosmetic manufacturing plant in Poland. Detergents were the main products being manufactured 
on the days that the samples were collected. From the time of sample collection, all samples were stored in a refrigerator at $4{ }^{\circ} \mathrm{C}$ until the time of analysis. Prior to analysis, the samples were stirred and the determinations of chemical parameters according to EN or ISO standards were performed. These parameters included: COD, COD of dissolved substances (after filtration using $0.45 \mu \mathrm{m}$ filter) (ISO 6060), total suspended solids (TSS) (EN 872), pH (EN ISO 10523), turbidity (EN ISO 7027), conductivity (EN 27888), alkalinity (ISO 740), and anionic surfactants (EN 903). Petroleum ether extractable organics (PEEO) were gravimetrically determined by the extraction of a $500 \mathrm{~cm}^{3}$ sample with petroleum ether $\left(50+50 \mathrm{~cm}^{3}\right)$. The results of all determinations are given as the average of three independent measurements.

Stirred wastewater was left for $30 \mathrm{~min}$ for sedimentation in order to eliminate easily settling solids (ESS). The wastewater after sedimentation was further treated with the following processes: C/S, C/DAF and FP. All the studies were carried out within $72 \mathrm{~h}$ of the sample collection.

In the studies of the $\mathrm{C} / \mathrm{S}$ process, $\mathrm{FeCl}_{3}$ and coagulants based on $\mathrm{Al}^{3+}\left(\mathrm{Al}_{2}\left(\mathrm{SO}_{4}\right)_{3}\right.$, PAX 16, PAX 19, Al 1019, Al 3010, Al 3030, Al 3035) have been employed. $\mathrm{FeCl}_{3}$ and $\mathrm{Al}_{2}\left(\mathrm{SO}_{4}\right)_{3}$ were added to wastewater samples in the form of a solution of the concentration of $100 \mathrm{~g} \mathrm{Fe}^{3+} / \mathrm{dm}^{3}$ and $50 \mathrm{~g} \mathrm{Al}^{3+} / \mathrm{dm}^{3}$, respectively. The dosage range was $500-1500$ $\mathrm{mg} / \mathrm{dm}^{3}$. Commercial solutions of coagulants Al (Brenntag, ) and PAX (Kemipol) were added to wastewater as supplied by the manufacturer without further preparation, in the range $1-20 \mathrm{~cm}^{3} / \mathrm{dm}^{3}$. The characteristic parameters of the coagulants are presented in Table 1.

Table 1

Parameters of commercial coagulants [21, 22]

\begin{tabular}{|l|c|c|c|c|c|c|}
\hline \multicolumn{1}{|c|}{ Parameter } & PAX 16 & PAX 19 & Al 1019 & Al 3010 & Al 3030 & Al 3035 \\
\hline Manufacturer & Kemipol & Kemipol & Brenntag & Brenntag & Brenntag & Brenntag \\
\hline $\mathrm{Al}^{3+}, \mathrm{mg} / \mathrm{cm}^{3}$ & $100-107.5$ & $99.6-105.4$ & $159.8-177.9$ & $>126$ & $>108$ & $>108$ \\
\hline Chlorides, \% & $8 \pm 2$ & $5.5 \pm 0.5$ & $7.0-11.0$ & $<6.5$ & $<6.0$ & $<6.0$ \\
\hline $\mathrm{pH}$ & $<1$ & $4.0 \pm 0.5$ & $3.1-3.9$ & $>4.1$ & 3.8 & 3.7 \\
\hline Alkalinity, mmol $\left./ \mathrm{dm}^{3}\right]$ & $<40$ & $85 \pm 5$ & $80-90$ & $>70$ & $>70$ & $>90$ \\
\hline
\end{tabular}

For the studies of the $\mathrm{C} / \mathrm{S}$ process, a wastewater sample of $0.5 \mathrm{dm}^{3}$ in volume was used. After adding $\mathrm{Al}$ coagulants, $\mathrm{pH}$ was adjusted to 7.0 (Elmetron CPC-505pH-meter readings) by means of $1 \mathrm{M} \mathrm{HCl}$ or $3 \mathrm{M} \mathrm{NaOH}$. Coagulation using $\mathrm{FeCl}_{3}$ was performed at $\mathrm{pH} 6.0$ and 9.0. The $\mathrm{pH}$ values were chosen based on previous studies [7,8]. All reagents were added during $5 \mathrm{~min}$ of rapid stirring $(500 \mathrm{rpm})$. Next, wastewater was stirred for additional $10 \mathrm{~min}$ using slow rate $(50 \mathrm{rpm})$. In the case of some of the coagulants $\left(\mathrm{FeCl}_{3}, \mathrm{Al}_{2}\left(\mathrm{SO}_{4}\right)_{3}\right.$ and PAX 16), the coagulation process was supported by 
Flopam AN913SH anionic flocculant prepared as water solution of $0.5 \mathrm{~g} / \mathrm{dm}^{3}$. The flocculant was added after rapid stirring in the amount of $2 \mathrm{mg} / \mathrm{dm}^{3}$, which was found to be optimal based on our previous experiments $[13,14]$. After flocculation, the wastewater was left for sedimentation in a measuring cylinder. Then, the parameters of treated wastewater and the volume of the sludge were determined. The criteria for the determination of the optimal dose of coagulant included the minimal COD value and the minimal volume of the sludge.

In the case of $\mathrm{C} / \mathrm{DAF}$, the following coagulants were chosen: $\mathrm{Al}_{2}\left(\mathrm{SO}_{4}\right)_{3}, \mathrm{Al} 1019$ and $\mathrm{Al}$ 3010. Dosage range was $500-1500 \mathrm{mg} / \mathrm{dm}^{3}$ for $\mathrm{Al}_{2}\left(\mathrm{SO}_{4}\right)_{3}$ and $1-10$ for $\mathrm{Al} 1019$ and $\mathrm{Al} 3010$. After the preliminary studies, the $\mathrm{FeCl}_{3}$ coagulant was excluded from analysis due to the observed difficulties with sludge separation by flotation. All experiments were carried out using a wastewater sample of $1 \mathrm{dm}^{3}$ in volume. After adding the coagulants, $\mathrm{pH}$ was adjusted to the value of 7.0. The optimal value of $\mathrm{pH}$ was determined based on the results of previous experiments $[13,14]$. Reagents were added during the phase of rapid stirring lasting for $5 \mathrm{~min}(500 \mathrm{rpm})$. After that, $12 \mathrm{mg} / \mathrm{dm}^{3}$ of the flocculant (an amount of previously established to be optimal) was added and the sample was stirred slowly for $30 \mathrm{~s}(50 \mathrm{rpm})$. After flocculation, the wastewater was transferred to a dissolved air flotation unit of the volume of $1 \mathrm{dm}^{3}$, saturated with air compressed to $0.6 \mathrm{MPa}$, stirred several times and placed in the horizontal position in order to provide the greatest possible area for interfacial exchange. After 5 min of standby, the flotation unit was emptied by means of a discharge valve. The constant pressure of $0.6 \mathrm{MPa}$ was maintained over the solution surface during this process. The wastewater was transferred to the flotation reactor, where the sludge was separated from the treated wastewater and the pressure was decreased to atmospheric. After the separation phase, the parameters of treated wastewater and the volume of sludge were determined. The experiments were carried out at ambient temperature $\left(20^{\circ} \mathrm{C}\right)$.

Wastewater recirculation during $\mathrm{C} / \mathrm{DAF}$ process was employed, because of high amount of sludge that was created. Wastewater samples after the C/DAF process and sediment separation were mixed with raw wastewater in the ratio of $1: 1$ and $2: 1$ (treated:raw wastewater). The prepared wastewater mixture was then subjected to the C/DAF process.

Studies involving FP were carried out in the reactor of $1 \mathrm{dm}^{3}$ volume. Acidic $\mathrm{FeSO}_{4}$ solution with the concentration of $50 \mathrm{~g} \mathrm{Fe}^{2+} / \mathrm{dm}^{3}$ and $30 \% \mathrm{H}_{2} \mathrm{O}_{2}$ solution was used as reagents. The process was performed in $\mathrm{pH} 3.0$. In order to determine the process efficiency, the samples were collected after 5, 15, 30 and $60 \mathrm{~min}$. After the selected periods of time, the process was stopped by adjusting the $\mathrm{pH}$ value to 9.0. In all experiments, $\mathrm{pH}$ adjustment was performed by means of $3 \mathrm{M} \mathrm{NaOH}$ and $1 \mathrm{M} \mathrm{H}_{2} \mathrm{SO}_{4}$. $\mathrm{pH}$ of 9.0 was used in the final neutralization/coagulation step to guarantee the complete decomposition of the remaining $\mathrm{H}_{2} \mathrm{O}_{2}$ during the night. The efficiency of hydrogen peroxide $(\eta)$ was estimated according to Kang and Hwang [23]: 


$$
\eta=\frac{\Delta \mathrm{COD}}{0.476\left[\mathrm{H}_{2} \mathrm{O}_{2}\right]} \times 100 \%
$$

where: $\triangle \mathrm{COD}$ is the decrease in the COD value $\left(\mathrm{mg} \mathrm{O}_{2} / \mathrm{dm}^{3}\right), 0.4706$ is a constant factor for the amount of COD theoretically removed (mg) by $1 \mathrm{mg}$ of $\mathrm{H}_{2} \mathrm{O}_{2},\left[\mathrm{H}_{2} \mathrm{O}_{2}\right]$ is the hydrogen peroxide dose $\left(\mathrm{mg} / \mathrm{dm}^{3}\right)$.

All reagents used in this study were manufactured by $\mathrm{POCH}$ and were of puriss p.a. grade.

\section{RESULTS AND DISCUSSION}

\subsection{CHARACTERISTICS OF RAW WASTEWATER}

The most important parameters of cosmetic wastewater are presented in Table 2 . The wastewater was characterized by high values of the following parameters: COD, TSS, anionic surfactants and PEEO.

Table 2

Parameters of raw wastewater

\begin{tabular}{|l|c|c|c|}
\hline \multicolumn{1}{|c|}{ Parameter } & 1 & 2 & 3 \\
\hline $\mathrm{pH}$ & 5.1 & 6.35 & 6.3 \\
\hline Conductivity, $\mathrm{mS} / \mathrm{cm}$ & 1.18 & 1.49 & 1.25 \\
\hline $\mathrm{COD}, \mathrm{mg} \mathrm{O}_{2} / \mathrm{dm}^{3}$ & 13160 & 13580 & 9410 \\
\hline $\mathrm{COD}_{\text {dis }}, \mathrm{mg} \mathrm{O}_{2} / \mathrm{dm}^{3}$ & 11230 & 11190 & 7530 \\
\hline $\mathrm{BOD}_{5}, \mathrm{mg} \mathrm{O} / \mathrm{dm}^{3}$ & 1480 & 6020 & 740 \\
\hline $\mathrm{PEEO}, \mathrm{mg} / \mathrm{dm}^{3}$ & 790 & 800 & 520 \\
\hline $\mathrm{TSS}, \mathrm{mg} / \mathrm{dm}^{3}$ & 4750 & 4490 & 5370 \\
\hline $\mathrm{ESS}, \mathrm{cm}^{3} / \mathrm{dm}^{3}$ & $<0.5$ & $<0.5$ & $<0.5$ \\
\hline Turbidity, NTU & 3500 & 3500 & 3000 \\
\hline Alkalinity, mmol $/ \mathrm{dm}^{3}$ & 4.6 & 3.3 & 3.2 \\
\hline Anionic surfactants, $\mathrm{mg} / \mathrm{dm}^{3}$ & 3000 & 4500 & 4000 \\
\hline
\end{tabular}

The COD values were within the range of 9410 (sample 3)-13 $580 \mathrm{mg} \mathrm{O} / \mathrm{dm}^{3}$ (sample 2) and were significantly higher than those presented in our previous publications $[7,8,15]$. The investigated samples were characterized by a high content of TSS, ranging from 4490 (sample 2) to $5370 \mathrm{mg} / \mathrm{dm}^{3}$ (sample 3). The TSS was of the mineralorganic type and their contribution in the COD varied from 14.7 (sample 1) to $20.0 \%$ (sample 3). The presence of only a small amount of ESS $\left(<0.5 \mathrm{~cm}^{3} / \mathrm{dm}^{3}\right)$ proves the proper functioning of the equalizing tank, which also acts as a sedimentation tank. Wastewater samples varied with respect to their susceptibility to biological treatment. 
Sample 2 was susceptible to biological treatment: $\mathrm{BOD}_{5} / \mathrm{COD}$ was equal to 0.44 contrary to sample 1 and 3, for which the value of this parameter was equal to 0.11 and 0.08 , respectively. Despite the fact that contaminants in sample 2 were susceptible to biochemical degradation, this wastewater cannot be disposed of directly to municipal sewage system without previous pre-treatment due to relatively high levels of $\mathrm{BOD}_{5}$ $\left(6020 \mathrm{mg} \mathrm{O} / \mathrm{dm}^{3}\right)$. All samples contained high amounts of anionic surfactants $(>3000$ $\mathrm{mg} / \mathrm{dm}^{3}$ ), which promoted the dissolution of high amounts of hydrophobic substances in the water phase. Surfactants were the major, but not dominant organic compounds in wastewater. The high values of PEEO $\left(520-800 \mathrm{mg} / \mathrm{dm}^{3}\right)$ in the investigated samples support this conclusion.

\subsection{TREATMENT PROCESSES}

Results of the studies on the $\mathrm{C} / \mathrm{S}$ process are given in Tables 3-8. For all three wastewater samples, $\mathrm{C} / \mathrm{S}$ has proven to be very effective. The maximum $\mathrm{COD}$ removal was $88.2,91.6$ and $82.6 \%$, for samples 1,2 and 3, respectively. Such a high efficiency was also influenced by the presence (in all samples) of fine suspensions, easily undergoing coagulation. For dissolved substances, the COD value decreased by $86.2,89.8$ and $78.2 \%$, respectively. In the treated samples, levels of COD were still very high.

Table 3

Parameters of wastewater after $\mathrm{C} / \mathrm{S}$ in the sample 1 for $\mathrm{FeCl}_{3}$ and $\mathrm{Al}_{2}\left(\mathrm{SO}_{4}\right)_{3}$ coagulants

\begin{tabular}{|l|c|c|c|c|c|c|}
\hline Coagulant & $\mathrm{pH}$ & $\begin{array}{c}\text { Coagulant dose } \\
{\left[\mathrm{mg} / \mathrm{dm}^{3}\right]}\end{array}$ & Flocculant & $\begin{array}{c}\mathrm{COD} \\
{\left[\mathrm{mg} \mathrm{O}_{2} / \mathrm{dm}^{3}\right]}\end{array}$ & $\begin{array}{c}\mathrm{BOD} 5 \\
{\left[\mathrm{mg} \mathrm{O}_{2} / \mathrm{dm}^{3}\right]}\end{array}$ & $\begin{array}{c}\text { Sludge volume } \\
{\left[\mathrm{cm}^{3} / \mathrm{dm}^{3}\right]}\end{array}$ \\
\hline $\mathrm{FeCl}_{3}$ & 6.0 & 800 & - & 1548 & 121 & 100 \\
\hline $\mathrm{FeCl}_{3}$ & 6.0 & 700 & + & 1646 & 118 & 100 \\
\hline $\mathrm{FeCl}_{3}$ & 9.0 & 1000 & - & 2130 & 119 & 160 \\
\hline $\mathrm{FeCl}_{3}$ & 9.0 & 900 & + & 2130 & 119 & 160 \\
\hline $\mathrm{Al}_{2}\left(\mathrm{SO}_{4}\right)_{3}$ & 7.0 & 1000 & - & 2612 & 120 & 180 \\
\hline $\mathrm{Al}_{2}\left(\mathrm{SO}_{4}\right)_{3}$ & 7.0 & 900 & + & 2032 & 119 & 180 \\
\hline
\end{tabular}

Table 4

Parameters of wastewater after $\mathrm{C} / \mathrm{S}$ in the sample 1 for $\mathrm{Al}$ and $\mathrm{PAX}$ coagulants

\begin{tabular}{|l|c|c|c|c|c|c|}
\hline Coagulant & $\mathrm{pH}$ & $\begin{array}{c}\text { Coagulant dose } \\
{\left[\mathrm{cm}^{3} / \mathrm{dm}^{3}\right]}\end{array}$ & Flocculant & $\begin{array}{c}\mathrm{COD} \\
{\left[\mathrm{mg} \mathrm{O}_{2} / \mathrm{dm}^{3}\right]}\end{array}$ & $\begin{array}{c}\mathrm{BOD}_{5} \\
{\left[\mathrm{mg} \mathrm{O}_{2} / \mathrm{dm}^{3}\right]}\end{array}$ & $\begin{array}{c}\text { Sludge volume } \\
{\left[\mathrm{cm}^{3} / \mathrm{dm}^{3}\right]}\end{array}$ \\
\hline Al 3010 & 7.0 & 5 & - & 2130 & - & 140 \\
\hline Al 1019 & 7.0 & 5 & - & 2516 & - & 200 \\
\hline PAX 16 & 7.0 & 10 & - & 2130 & 118 & 360 \\
\hline PAX 16 & 7.0 & 9 & + & 1934 & 122 & 360 \\
\hline PAX 19 & 7.0 & 10 & - & 2514 & - & 180 \\
\hline
\end{tabular}


Table 5

Parameters of wastewater after the $\mathrm{C} / \mathrm{S}$ in the sample 2 for $\mathrm{FeCl}_{3}$ and $\mathrm{Al}_{2}\left(\mathrm{SO}_{4}\right)_{3}$ coagulants

\begin{tabular}{|l|c|c|c|c|c|c|}
\hline Coagulant & $\mathrm{pH}$ & $\begin{array}{c}\text { Coagulant dose } \\
{\left[\mathrm{mg} / \mathrm{dm}^{3}\right]}\end{array}$ & Flocculant & $\begin{array}{c}\mathrm{COD} \\
{\left[\mathrm{mg} \mathrm{O}_{2} / \mathrm{dm}^{3}\right]}\end{array}$ & $\begin{array}{c}\mathrm{BOD}_{5} \\
{\left[\mathrm{mg} \mathrm{O}_{2} / \mathrm{dm}^{3}\right]}\end{array}$ & $\begin{array}{c}\text { Sludge volume } \\
{\left[\mathrm{cm}^{3} / \mathrm{dm}^{3}\right]}\end{array}$ \\
\hline $\mathrm{FeCl}_{3}$ & 6.0 & 900 & - & 5550 & 2410 & 100 \\
\hline $\mathrm{FeCl}_{3}$ & 6.0 & 850 & + & 5290 & 2290 & 100 \\
\hline $\mathrm{FeCl}_{3}$ & 9.0 & 800 & - & 9370 & 1950 & 170 \\
\hline $\mathrm{FeCl}_{3}$ & 9.0 & 750 & + & 8500 & 2320 & 170 \\
\hline $\mathrm{Al}_{2}\left(\mathrm{SO}_{4}\right)_{3}$ & 7.0 & 900 & - & 1530 & 773 & 185 \\
\hline $\mathrm{Al}_{2}\left(\mathrm{SO}_{4}\right)_{3}$ & 7.0 & 850 & + & 1512 & 547 & 185 \\
\hline
\end{tabular}

Table 6

Parameters of wastewater after the $\mathrm{C} / \mathrm{S}$ in the sample 2 for $\mathrm{Al}$ and $\mathrm{PAX}$ coagulants

\begin{tabular}{|l|c|c|c|c|c|c|}
\hline Coagulant & $\mathrm{pH}$ & $\begin{array}{c}\text { Coagulant dose } \\
{\left[\mathrm{cm}^{3} / \mathrm{dm}^{3}\right]}\end{array}$ & Flocculant & $\begin{array}{c}\mathrm{COD} \\
{\left[\mathrm{mg} \mathrm{O}_{2} / \mathrm{dm}^{3}\right]}\end{array}$ & $\begin{array}{c}\mathrm{BOD}_{5} \\
{\left[\mathrm{mg} \mathrm{O}_{2} / \mathrm{dm}^{3}\right]}\end{array}$ & $\begin{array}{c}\text { Sludge volume } \\
{\left[\mathrm{cm}^{3} / \mathrm{dm}^{3}\right]}\end{array}$ \\
\hline A1 3010 & 7.0 & 5 & - & 2486 & 973 & 140 \\
\hline A1 1019 & 7.0 & 6 & - & 1146 & 952 & 210 \\
\hline PAX 16 & 7.0 & 18 & - & 1720 & 1110 & 355 \\
\hline PAX 16 & 7.0 & 17 & + & 1512 & 538 & 355 \\
\hline PAX 19 & 7.0 & 10 & - & 1720 & - & 170 \\
\hline
\end{tabular}

Table 7

Parameters of wastewater after the $\mathrm{C} / \mathrm{S}$ in the sample 3 for $\mathrm{FeCl}_{3}$ and $\mathrm{Al}_{2}\left(\mathrm{SO}_{4}\right)_{3}$ coagulants

\begin{tabular}{|l|c|c|c|c|c|}
\hline Coagulant & $\mathrm{pH}$ & $\begin{array}{c}\text { Coagulant dose } \\
{\left[\mathrm{mg} / \mathrm{dm}^{3}\right]}\end{array}$ & Flocculant & $\begin{array}{c}\mathrm{COD} \\
{\left[\mathrm{mg} \mathrm{O}_{2} / \mathrm{dm}^{3}\right]}\end{array}$ & $\begin{array}{c}\text { Sludge volume } \\
{\left[\mathrm{cm}^{3} / \mathrm{dm}^{3}\right]}\end{array}$ \\
\hline $\mathrm{FeCl}_{3}$ & 6.0 & 700 & - & 6940 & 150 \\
\hline $\mathrm{FeCl}_{3}$ & 6.0 & 700 & + & 5100 & 150 \\
\hline $\mathrm{FeCl}_{3}$ & 9.0 & 800 & - & 4590 & 230 \\
\hline $\mathrm{FeCl}_{3}$ & 9.0 & 800 & + & 6910 & 230 \\
\hline $\mathrm{Al}_{2}\left(\mathrm{SO}_{4}\right)_{3}$ & 7.0 & 700 & - & 2200 & 440 \\
\hline $\mathrm{Al}_{2}\left(\mathrm{SO}_{4}\right)_{3}$ & 7.0 & 700 & + & 2150 & 440 \\
\hline
\end{tabular}

Table 8

Parameters of wastewater after the $\mathrm{C} / \mathrm{S}$ in the sample 3 for $\mathrm{Al}$ and PAX coagulants

\begin{tabular}{|l|c|c|c|c|c|}
\hline Coagulant & $\mathrm{pH}$ & $\begin{array}{c}\text { Coagulant dose } \\
{\left[\mathrm{cm}^{3} / \mathrm{dm}^{3}\right]}\end{array}$ & Flocculant & $\begin{array}{c}\mathrm{COD} \\
{\left[\mathrm{mg} \mathrm{O}_{2} / \mathrm{dm}^{3}\right]}\end{array}$ & $\begin{array}{c}\text { Sludge volume } \\
{\left[\mathrm{cm}^{3} / \mathrm{dm}^{3}\right]}\end{array}$ \\
\hline $\mathrm{Al} 3010$ & 7.0 & 5 & - & 1640 & 260 \\
\hline $\mathrm{Al} \mathrm{1019}$ & 7.0 & 3 & - & 2110 & 230 \\
\hline PAX 16 & 7.0 & 7 & - & 2800 & 360 \\
\hline PAX 16 & 7.0 & 7 & + & 2800 & 360 \\
\hline PAX 19 & 7.0 & 6 & - & 2340 & 260 \\
\hline
\end{tabular}


Settling of coagulated fine suspensions may improve the effect of coagulation of dissolved substances. For sample 1, the highest effect was obtained by using $\mathrm{FeCl}_{3}$ at $\mathrm{pH}$ 6.0. Application of $\mathrm{FeCl}_{3}$ at $\mathrm{pH} 9.0$ and all aluminum-based coagulants allowed only a little less COD removal. For samples 2 and 3, the effect obtained by using $\mathrm{FeCl}_{3}$ was clearly worse than for the aluminum-based coagulants. For all three samples, $\mathrm{Al}_{2}\left(\mathrm{SO}_{4}\right)_{3}$ usage, resulted in slightly less COD decreasing than obtained with pre-hydrolyzed coagulants (PAX 16, Al 1019 and Al 3010). Aluminum coagulants doses, converted to $\mathrm{g} \mathrm{Al}^{3+} / \mathrm{dm}^{3}$, resulting in maximum COD removal for particular sample, did not differ significantly (c.a. $900 \mathrm{~g} \mathrm{Al}^{3+} / \mathrm{dm}^{3}$ ), but the doses were slightly higher in the case of PAX. The volume of the resulting sludge was always lowest for $\mathrm{FeCl}_{3}$ at $\mathrm{pH}$ 6.0. Sludge obtained by aluminum coagulants has a much larger volume and volume diversity than for iron based ones. The use of flocculants for coagulation conducted under optimum conditions does not improve its effect (Tables 3-8). For other conditions (coagulant, dose), the increase of COD removal was negligible or lower coagulant dose provides the identical effect.

Coagulation carried out in optimum conditions (Tables 3-8) slightly decreased the $\mathrm{BOD}_{5} / \mathrm{COD}$ ratio which indicates that hardly biodegradable and toxic substances were removed in lesser extent, than other easily biodegradable substances. Aloui et al. [5] investigated cosmetic wastewater with high concentration of surfactants and parameters very similar to those of the wastewater investigated in this study (COD $11423 \mathrm{mg} \mathrm{O} / 2 \mathrm{dm}^{3}, \mathrm{BOD}_{5}$ $2500 \mathrm{mg} \mathrm{O} / \mathrm{dm}^{3}$, anionic surfactants $3148 \mathrm{mg} / \mathrm{dm}^{3}$, TSS $250 \mathrm{mg} / \mathrm{dm}^{3}$, fat $600 \mathrm{mg} / \mathrm{dm}^{3}$ ). The COD removal equal to $49.3 \%$ achieved by using $\mathrm{Al}_{2}\left(\mathrm{SO}_{4}\right)_{3}$ was significantly lower than that reported in this study. To a greater extent, anionic surfactants have been removed by $59.0 \%$.

It is more difficult to compare present results with those obtained by El-Gohary et al. [4]. They investigated wastewater with a different composition and much lower concentration of pollutants (COD $2276 \mathrm{mg} \mathrm{O} 2 / \mathrm{dm}^{3}$ ), but much larger amount of TSS (30-40\% of COD). Using $\mathrm{FeCl}_{3}, \mathrm{FeSO}_{4}$ and $\mathrm{Al}_{2}\left(\mathrm{SO}_{4}\right)_{3}$, they obtained the $\mathrm{COD}$ removal in the range of 75.8-77.5, being slightly lower than that obtained in this study. In our earlier studies [7] on cosmetic wastewater with a different composition and similar share of TSS, the values of COD removal achieved by using $\mathrm{FeCl}_{3}$ and $\mathrm{Al}_{2}\left(\mathrm{SO}_{4}\right)_{3}$ were lower and did not exceed $63.5 \%$ probably due to the different composition of treated wastewater.

The effect of coagulation depends on the quality and concentration of the pollutants. For sample 1, the best results obtained by using $\mathrm{FeCl}_{3}$ at $\mathrm{pH} 6.0$ indicate a large contribution of the neutralization of negative charges as a mechanism of pollutants removal. However, not much worse effect obtained by using $\mathrm{FeCl}_{3}$ at $\mathrm{pH} 9.0$ and aluminum based coagulants is evidence for adsorption of pollutants on resulting flocks.

For samples 2 and 3, the poor effect with $\mathrm{FeCl}_{3}$ and much better using aluminum based coagulants at high doses shows a significant contribution of sweep coagulation in the aluminium hydroxide precipitate [4] as a removal mechanism. 
Susceptibility to $\mathrm{C} / \mathrm{S}$ by using $\mathrm{Al}$ salt was very high for all investigated wastewater samples. Decrease in COD values ranged from 70.3 to $91.6 \%$. Only one Al coagulant, which would be the best for all the investigated samples, cannot be pointed out. For sample 1 (Table 3), the highest efficiency (83.8\%) was obtained in the $\mathrm{C} / \mathrm{S}$ process using PAX16 at a dose of $10 \mathrm{~cm}^{3} / \mathrm{dm}^{3}$. Application of Al 1019 at the dose of $6 \mathrm{~cm}^{3} / \mathrm{dm}^{3}$ for sample 2 resulted in the best effect, obtaining 91.6\% COD removal $\left(1146 \mathrm{mg} \mathrm{O}_{2} / \mathrm{dm}^{3}\right)$. Sample 3 was the most effectively treated by using Al 3010 at a dose of $5 \mathrm{~cm}^{3} / \mathrm{dm}^{3}$, which allowed us to obtain $82.6 \% \mathrm{COD}$ removal $\left(1640 \mathrm{mg} \mathrm{O} / \mathrm{dm}^{3}\right)$. In the $\mathrm{C} / \mathrm{S}$ process, it was possible to remove the whole TSS (and related COD values) and it was also possible to decrease $\mathrm{COD}_{\text {dis }}$ values and increase removal rates from 62.8 (sample 3, PAX 16, dose $7 \mathrm{~cm}^{3} / \mathrm{dm}^{3}$ ) to $87.8 \%$ (sample 2, Al 1019, $10 \mathrm{~cm}^{3} / \mathrm{dm}^{3}$ ). The lowest differences in the process efficiency $(4.4 \%$ COD removal) depending on the aluminum coagulant used, were observed in sample 1, while the biggest differences (12.4\%) were noticed in sample 3. Based on the estimated optimal doses (Tables 4, 6 and 8) of pre-hydrolyzed aluminum coagulants, it was concluded that the application of higher volumes of PAX coagulants than other Al coagulants is necessary to achieve higher efficiency of the process. Based on the parameters of the employed coagulants (Table 1), the amounts of coagulant in $\mathrm{g} \mathrm{Al}^{3+} / \mathrm{dm}^{3}$ are similar despite the differences in the doses $\left(\mathrm{cm}^{3} / \mathrm{dm}^{3}\right)$. The highest volume of sludge after treatment with commercial aluminum coagulants was observed for PAX 16.

Susceptibility of wastewater to $\mathrm{C} / \mathrm{S}$ process using $\mathrm{FeCl}_{3}$ differed significantly and depended on the sample used and $\mathrm{pH}$ of the wastewater. The lowest efficiency of $\mathrm{C} / \mathrm{S}$ process was obtained for sample 3 ranging from 26.3 (dose $700 \mathrm{mg} \mathrm{Fe} \mathrm{F}^{3+} / \mathrm{dm}^{3}, \mathrm{pH} \mathrm{6.0)}$ to $51.3 \%$ (dose $800 \mathrm{mg} \mathrm{Fe}{ }^{3+} / \mathrm{dm}^{3}$, pH 9.0). The highest efficiency of $\mathrm{C} / \mathrm{S}$ process was reported for sample 1 and it ranged from 83.8 (dose $1000 \mathrm{mg} \mathrm{Fe}^{3+} / \mathrm{dm}^{3}, \mathrm{pH} 9.0$ ) to $88.2 \%$ (dose $8000 \mathrm{mg} \mathrm{Fe}^{3+} / \mathrm{dm}^{3}$, pH 6.0). In the $\mathrm{C} / \mathrm{S}$ process employing $\mathrm{FeCl}_{3}$, the whole TSS was removed (and corresponding COD value) and the decrease in COD corresponding to the removal of dissolved substances varied from 7.8 (sample 3, dose $700 \mathrm{mg}$ $\mathrm{Fe}^{3+} / \mathrm{dm}^{3}, \mathrm{pH} 6.0$ ) to $86.2 \%$ (sample $1,800 \mathrm{mg} \mathrm{Fe}^{3+} / \mathrm{dm}^{3}, \mathrm{pH} 6.0$ ). The lowest differences in the efficiency of the process using $\mathrm{FeCl}_{3}$ were observed for sample $1(4.4 \%)$, while the biggest differences (28.8\%) were noticed for sample 2. Based on the efficiency of $\mathrm{C} / \mathrm{S}$ process using iron salts it is not possible to determine the $\mathrm{pH}$ value, at which this process should be performed. In the $\mathrm{C} / \mathrm{S}$ process using $\mathrm{FeCl}_{3}$ at $\mathrm{pH}$ 9.0, the higher amount of sludge was formed (with respect to the added iron) than in the case of the process at $\mathrm{pH} 6.0$.

The application of flocculant resulted in the increase in the efficiency of the process using aluminum coagulants up to $4.4 \%$. The concomitant decrease in dose by $10 \%$ resulted in no change observed in the sludge volume. Therefore, no significant influence on the $\mathrm{C} / \mathrm{S}$ process using $\mathrm{FeCl}_{3}$ was observed when flocculant was employed.

The efficiency of $\mathrm{C} / \mathrm{S}$ process was evident not only based on the COD removal. Almost $100 \%$ removal of color and turbidity was also an additional effect of this process 
(data not shown). In the case of color removal, the removal process involved co-sedimentation or adsorption rather than coagulation. In the case of $\mathrm{C} / \mathrm{S}$ with iron coagulants, the change in color was observed in pre-treated wastewater and it was associated with the presence of not completely separated iron (III) hydroxide or soluble iron complexes. When the new color was observed, the prolongation of the sedimentation time did not lead to its removal. This effect was permanent and lasted over $48 \mathrm{~h}$ after the end of the process.

Table 9

Parameters of wastewater after the C/DAF

\begin{tabular}{|c|c|c|c|c|}
\hline Sample & Coagulant & $\mathrm{Al}_{2}\left(\mathrm{SO}_{4}\right)_{3}$ & $\mathrm{Al} 3010$ & Al 1019 \\
\hline \multirow{3}{*}{1} & COD & $2806 \mathrm{mg} \mathrm{O}_{2} / \mathrm{dm}^{3}$ & $3580 \mathrm{mg} \mathrm{O}_{2} / \mathrm{dm}^{3}$ & $3290 \mathrm{mg} \mathrm{O}_{2} / \mathrm{dm}^{3}$ \\
\hline & dose & $1000 \mathrm{mg} / \mathrm{dm}^{3}$ & $4 \mathrm{~cm}^{3} / \mathrm{dm}^{3}$ & $4 \mathrm{~cm}^{3} / \mathrm{dm}^{3}$ \\
\hline & sludge volume & $500 \mathrm{~cm}^{3} / \mathrm{dm}^{3}$ & $180 \mathrm{~cm}^{3} / \mathrm{dm}^{3}$ & $220 \mathrm{~cm}^{3} / \mathrm{dm}^{3}$ \\
\hline \multirow{3}{*}{2} & Coagulant & $\mathrm{Al}_{2}\left(\mathrm{SO}_{4}\right)_{3}$ & $\mathrm{Al} 3010$ & Al 1019 \\
\hline & COD & $2688 \mathrm{mg} \mathrm{O}_{2} / \mathrm{dm}^{3}$ & $2688 \mathrm{mg} \mathrm{O}_{2} / \mathrm{dm}^{3}$ & $2480 \mathrm{mg} \mathrm{O}_{2} / \mathrm{dm}^{3}$ \\
\hline & Dose & $700 \mathrm{mg} / \mathrm{dm}^{3}$ & $5 \mathrm{~cm}^{3} / \mathrm{dm}^{3}$ & $3 \mathrm{~cm}^{3} / \mathrm{dm}^{3}$ \\
\hline
\end{tabular}

Table 10

Wastewater parameters after the $\mathrm{C} / \mathrm{DAF}$ simulated recirculation

\begin{tabular}{|c|c|c|c|c|c|c|c|}
\hline Sample & Coagulant & $\mathrm{Al}_{2}\left(\mathrm{SO}_{4}\right)_{3}$ & $\mathrm{Al} 3010$ & Al 1019 & $\mathrm{Al}_{2}\left(\mathrm{SO}_{4}\right)_{3}$ & Al 3010 & Al 1019 \\
\hline \multirow{4}{*}{1} & $\begin{array}{l}\text { Raw to treated } \\
\text { wastewater ratio }\end{array}$ & - & - & - & - & $1 / 2$ & $1 / 2$ \\
\hline & $\mathrm{COD}, \mathrm{mg} \mathrm{O}_{2} / \mathrm{dm}^{3}$ & - & - & - & - & 2322 & 2128 \\
\hline & Sludge volume, $\mathrm{cm}^{3} / \mathrm{dm}^{3}$ & - & - & - & - & 150 & 130 \\
\hline & $\mathrm{BOD}_{5}, \mathrm{mg} \mathrm{O}_{2} / \mathrm{dm}^{3}$ & - & - & - & - & 119 & 119 \\
\hline \multirow{5}{*}{2} & Coagulant & $\mathrm{Al}_{2}\left(\mathrm{SO}_{4}\right)_{3}$ & $\mathrm{Al} 3010$ & Al 1019 & $\mathrm{Al}_{2}\left(\mathrm{SO}_{4}\right)_{3}$ & $\mathrm{Al} 3010$ & Al 1019 \\
\hline & $\begin{array}{l}\text { Raw to treated } \\
\text { wastewater ratio }\end{array}$ & $1 / 1$ & $1 / 1$ & $1 / 1$ & $1 / 2$ & $1 / 2$ & $1 / 2$ \\
\hline & $\mathrm{COD}, \mathrm{mg} \mathrm{O}_{2} / \mathrm{dm}^{3}$ & 2294 & 3250 & 2294 & 2104 & 1720 & 1530 \\
\hline & Sludge volume, $\mathrm{cm}^{3} / \mathrm{dm}^{3}$ & 600 & 150 & 170 & 450 & 90 & 150 \\
\hline & $\mathrm{BOD}_{5}, \mathrm{mg} \mathrm{O}_{2} / \mathrm{dm}^{3}$ & - & - & - & 790 & 501 & 1140 \\
\hline \multirow{4}{*}{3} & Coagulant & $\mathrm{Al}_{2}\left(\mathrm{SO}_{4}\right)_{3}$ & $\mathrm{Al} 3010$ & $\mathrm{Al} 1019$ & $\mathrm{Al}_{2}\left(\mathrm{SO}_{4}\right)_{3}$ & $\mathrm{Al} 3010$ & Al 1019 \\
\hline & $\begin{array}{l}\text { Raw to treated } \\
\text { wastewater ratio }\end{array}$ & $1 / 1$ & $1 / 1$ & $1 / 1$ & $1 / 2$ & $1 / 2$ & $1 / 2$ \\
\hline & $\mathrm{COD}, \mathrm{mg} \mathrm{O}_{2} / \mathrm{dm}^{3}$ & 2704 & 2688 & 2720 & 2526 & 2560 & 2480 \\
\hline & Sludge volume, $\mathrm{cm}^{3} / \mathrm{dm}^{3}$ & 450 & 120 & 120 & 350 & 100 & 100 \\
\hline
\end{tabular}

The C/DAF process efficiency (Tables 9,10 ) for raw wastewater samples varied from 71.4 (sample 3, $\mathrm{Al}_{2}\left(\mathrm{SO}_{4}\right)_{3}$ dose $700 \mathrm{mg} \mathrm{Al}{ }^{3+} / \mathrm{dm}^{3}$ and sample 3, Al 3010 dose $5 \mathrm{~cm}^{3} / \mathrm{dm}^{3}$ ) to $78.7 \%$ (sample $1, \mathrm{Al}_{2}\left(\mathrm{SO}_{4}\right)_{3}$ dose $500 \mathrm{mg} \mathrm{Al}{ }^{3+} / \mathrm{dm}^{3}$ ). Application of $\mathrm{C} / \mathrm{DAF}$ process allowed for the elimination of TSS, color and turbidity (data not shown). 
As a result, the COD removal corresponding to the dissolved substances was equal to $64.3-75.0 \%$. The efficiency of the dissolved substances removal was lower in the $\mathrm{C} / \mathrm{DAF}$ process than in the $\mathrm{C} / \mathrm{S}$ process. The treatment efficiency of raw wastewater samples depended only to a small extent on the coagulant employed. The optimal doses of coagulants for C/DAF process were similar to those in the C/S process (Tables 9,10 ). As a result of the application of Al 3010 and $\mathrm{Al}$ 1019, smaller (sample 2 and 3) or similar (sample 1) volumes of sludge were obtained compared to the volumes obtained for $\mathrm{C} / \mathrm{S}$ process using similar doses of the coagulant. In the case of $\mathrm{Al}_{2}\left(\mathrm{SO}_{4}\right)_{3}$, such correlation was not observed. Due to the high volume of sludge, the recirculation was employed in $\mathrm{C} / \mathrm{DAF}$ process. The optimum dose of the coagulant used in C/DAF process was estimated with respect to the mixing ratio. The value of COD after the C/DAF process with recirculation for 1:2 raw to treated wastewater ratio varied from 2128 (sample 1, Al 1019) to $3250 \mathrm{mg} \mathrm{O}_{2} / \mathrm{dm}^{3}$ (sample 2, Al 3010), while for 2:1 ratio varied from 1530 (sample 2, Al 1019) to $2560 \mathrm{mg} \mathrm{O}_{2} / \mathrm{dm}^{3}$ (sample 3, Al 3010). The efficiency of C/DAF process with recirculation expressed as a degree of COD removal after mixing varied from 55.2 (sample 3, Al 1019) to $67.6 \%$ (sample 1, Al 1019) for $1: 1$ raw to treated wastewater ratio, and from 42.1 (sample $3, \mathrm{Al} 3010$ ) to $48.7 \%$ ( sample $3, \mathrm{Al}_{2}\left(\mathrm{SO}_{4}\right)_{3}$ ) for 1:2 raw to treated wastewater ratio. The efficiency of C/DAF process with respect to COD value for raw wastewater ranged from 71.1 (sample 3, Al 1019 recirculation, 1:1 raw to treated wastewater ratio) to $88.7 \%$ (sample 2 , Al 1019, recirculation, $1: 2$ raw to treated wastewater ratio). The determined values of COD, TSS and PEEO in raw and treated wastewater show that $\mathrm{C} / \mathrm{S}$ and $\mathrm{C} / \mathrm{DAF}$ processes may be successfully used in the treatment of this type of wastewater.

The optimal doses of iron and aluminum coagulants of $700-1000 \mathrm{mg} / \mathrm{dm}^{3}$ calculated with respect to the concentration of organics, expressed as COD (9410-13 $\left.580 \mathrm{mg} \mathrm{O} / 2 \mathrm{dm}^{3}\right)$ were lower than the doses used by El-Gohary et al. [4] $\left(700 \mathrm{mg} / \mathrm{dm}^{3}\right.$ of the coagulant and COD $2276 \mathrm{mg} \mathrm{O}_{2} / \mathrm{dm}^{3}$ ) and significantly lower than the doses used by Aloui et al. [5] (2000-4000 mg/dm ${ }^{3}$ of coagulant and COD $\left.11423 \mathrm{mg} \mathrm{O}_{2} / \mathrm{dm}^{3}\right)$. However, the amount of sludge formed after C/S was significantly greater and was as high as $440 \mathrm{~cm}^{3} / \mathrm{dm}^{3}$. During the $\mathrm{C} / \mathrm{S}$ process employing small doses of aluminum salts, the most important factors include the neutralization of permanent negative charge of organic contaminants and adsorption taking place on the floc, which is proved by the over $99 \%$ efficiency of the anionic surfactant and PEEO removal. Application of $\mathrm{C} / \mathrm{S}$ process led to decrease of the content of anionic surfactants from $3000-4500 \mathrm{mg} / \mathrm{dm}^{3}$ in raw wastewater sample to below $5 \mathrm{mg} / \mathrm{dm}^{3}$ (data not shown). The efficiency of removal of anionic surfactants was significantly higher than the efficiency obtained by Aloui et al. [5]. Such differences in the reported values of the efficiency may be caused by the differences in the qualitative and quantitative composition of wastewater or by the application of higher doses of $\mathrm{Al}_{2}\left(\mathrm{SO}_{4}\right)_{3}$. Foe high aluminum doses, the sweep coagulation prevails over the mechanism involving charge neutralization and adsorption [4]. Results obtained by using prehydrolyzed coagulants are consistent with the results obtained by Carballa et al. [24]. 
The polymeric structure of these coagulants results in high agglomeration and greater destabilization of negatively charged colloids. The efficiency of wastewater treatment reported by Aloui et al. [5] was lower than the efficiency obtained in the present study while the obtained parameters for treated wastewater were significantly higher despite the application of 3-4 times higher doses of coagulants and application of calcium oxide as floccule dead weight.

Addition of flocculants in $\mathrm{C} / \mathrm{S}$ usually led to the decrease in the amount of contaminants remaining in the wastewater after the process when compared to $\mathrm{C} / \mathrm{S}$ process without the application of flocculant. This was proved by the lower value of COD obtained in this process. The optimal doses of coagulant in the process employing flocculant were lower (except for sample 3). The acceleration of the coagulation process and formation of floccules is an additional benefit connected with the application of flocculant. In the $\mathrm{C} / \mathrm{S}$ process without flocculant, the resulting sludge settled slowly, while in the case of $\mathrm{C} / \mathrm{S}$ process with flocculant big, easily settled floccules were formed. The sedimentation time of such floccules was below $5 \mathrm{~min}$, which shows that this process is several times faster than sedimentation observed in the case of $\mathrm{C} / \mathrm{S}$ without flocculant. Additionally, the change in color was not observed. Sludge properties are a significant factor in the selection of the coagulant to be used [25].

The C/DAF efficiency was slightly lower than the C/S efficiency. Despite the fact that the coagulant doses for both processes were similar, the volume of the formed sludge was different. Floccules formed during the $\mathrm{C} / \mathrm{S}$ process were gravity-settled. The volume of the sludge was determined by the amount of suspensions and flocs density. In the C/DAF process, the sludge volume was the result of the two opposite forces - gravitation and buoyancy. Therefore, the sludge volume should be lower than in the case of $\mathrm{C} / \mathrm{S}$ process. However, flowing gas and flow rate may split flocs leading to an increase in the sludge volume. Depending on the prevailing factors, sludge volume in the C/DAF process may be either higher or lower when compared to the volume obtained in $\mathrm{C} / \mathrm{S}$ process.

Table 11

Wastewater parameters after the Fenton process for sample 2 and 60 min process

\begin{tabular}{|l|c|c|c|c|c|c|}
\hline Doses of $\mathrm{H}_{2} \mathrm{O}_{2} / \mathrm{Fe}^{2+}, \mathrm{g} / \mathrm{dm}^{3}$ & $15 / 5$ & $15 / 3$ & $12.5 / 4$ & $12.5 / 3$ & $10 / 3$ & $10 / 2$ \\
\hline Oxidant efficiency, \% & 66.9 & 117.8 & 147.8 & 102.9 & 168.5 & 108.3 \\
\hline $\mathrm{BOD}_{5}, \mathrm{mg} \mathrm{O}_{2} / \mathrm{dm}^{3}$ & 1540 & 2290 & 2150 & 2580 & 2650 & 2500 \\
\hline
\end{tabular}

The efficiency of the Fenton process is shown in Table 11 and Figs. 1, 2. The highest values of COD removal for sample 2 were equal to $64.0 \%$ (dose $12.5 / 4 \mathrm{~g} / \mathrm{dm}^{3}$ ) and $72.7 \%$ for sample 3 (doses $13 / 5$ and $10 / 4 \mathrm{~g} / \mathrm{dm}^{3}$ ). In most experiments, a similar change in the COD value over time was observed. A significant decrease was observed within the first $5 \mathrm{~min}$, which was followed by smaller changes ranging from 1.2 (sample 2, 
$12.5 / 4 \mathrm{~g} / \mathrm{dm}^{3}$ ) to $13.7 \%$ (sample $3,13 / 4 \mathrm{~g} / \mathrm{dm}^{3}$ ). A different trend in the changes of COD was observed for the process in which the $\mathrm{H}_{2} \mathrm{O}_{2}$ dose corresponded approximately to the COD value of raw wastewater and at the lowest $\mathrm{H}_{2} \mathrm{O}_{2} / \mathrm{Fe}^{2+}$ weight ratio (sample 2, $12.5 / 3 \mathrm{~g} / \mathrm{dm}^{3}$ and sample $3,10 / 4 \mathrm{~g} / \mathrm{dm}^{3}$ ). Comparing $\mathrm{FP}$ with $\mathrm{C} / \mathrm{S}$ employing $\mathrm{FeCl}_{3}$ at $\mathrm{pH} \mathrm{9.0,} \mathrm{it} \mathrm{may} \mathrm{be} \mathrm{stated} \mathrm{that} \mathrm{FP} \mathrm{is} \mathrm{significantly} \mathrm{more} \mathrm{effective} \mathrm{(by} 26.6$ and $21.4 \%$ ) irrespective of the employed doses of the reagents. However, it is less effective than the process employing aluminum coagulants.

Depending on the employed doses of the oxidant, the efficiency varied from 66.9 to $168.5 \%$. The highest efficiency of the oxidant was observed for $\mathrm{H}_{2} \mathrm{O}_{2}$ doses lower than the $\mathrm{COD}$ values and iron doses 3 times lower than the $\mathrm{H}_{2} \mathrm{O}_{2}$ doses (reagent ratio equal to $2.5 / 1,3.125 / 1$ and 3.33/1). However, the $\mathrm{H}_{2} \mathrm{O}_{2}$ dose is the limiting factor in this case. After exceeding the dose equal to the COD value, the efficiency of the oxidant decreases dramatically to $66.9 \%$. Increase in $\mathrm{H}_{2} \mathrm{O}_{2} / \mathrm{Fe}^{2+}$ mass ratio up to $5 / 1$ leads to the decrease in the oxidant efficiency. The reported efficiency significantly higher than $100 \%$ may be due to two reasons: contribution of final coagulation not requiring any oxidant and reaction of oxygen present in the sample with organic radicals formed in the reaction of hydroxyl radicals with organic contaminants.

Due to the high value of COD in the case of FP, it was necessary to use amounts of reagents higher than in the $\mathrm{C} / \mathrm{S}$ or $\mathrm{C} / \mathrm{DAF}$ processes. Additionally, because of significant amounts of $\mathrm{H}_{2} \mathrm{O}_{2}$ decomposing during the final coagulation, the final sedimentation was difficult.

The reason for the higher efficiency of $\mathrm{FP}$ compared to $\mathrm{C} / \mathrm{S}$ process using $\mathrm{FeCl}_{3}$ at pH 9.0 is chemical oxidation after which the final coagulation takes place. Final coagulation occurs between chemicals present in the wastewater from the beginning and new ones formed during the chemical oxidation. It is possible that some compounds formed during the oxidation are more susceptible to coagulation than their precursors. This factor may additionally lead to the increase in the efficiency of FP. However, it is more probable that the efficiency of the final coagulation is lower than the efficiency of coagulation obtained by means of $\mathrm{FeCl}_{3}$ at $\mathrm{pH}$ 9.0. This is caused by the fact that substances participating in coagulation are at the same time partly oxidized and products of the oxidation are less susceptible to coagulation. Therefore, the contribution of the Fenton reaction in the overall FP is higher than 26.6 and $21.4 \%$. However, it is not high enough to cause the Fenton reaction to be dominating in the overall FP. Probably the contribution of coagulation slowly decreases over time, while the contribution of the Fenton reaction quickly increases. The oxidation rate decreases over time due to the decrease in the amount of $\mathrm{H}_{2} \mathrm{O}_{2}$ being the reaction substrate. This explains the diminishing decrease in COD value after a long time. The course of the Fenton process depending on time and significant step decrease in COD value within the first $5 \mathrm{~min}$ of the process prove the dominating contribution of final neutralization/coagulation in the final efficiency of the treatment in the case of short times of the process. 


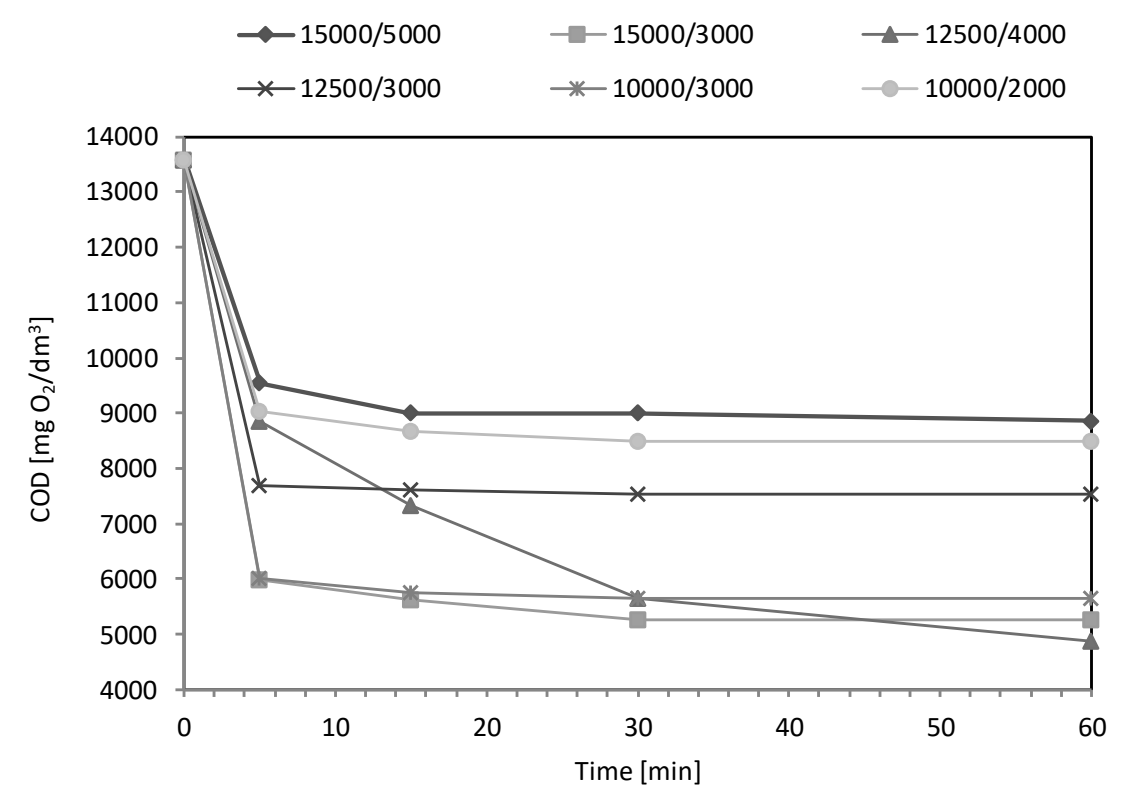

Fig. 1. Time dependence of COD during the Fenton process for sample 2 and $\mathrm{H}_{2} \mathrm{O}_{2} / \mathrm{Fe}^{2+}$ doses $\left(\mathrm{mg} / \mathrm{dm}^{3}\right)$

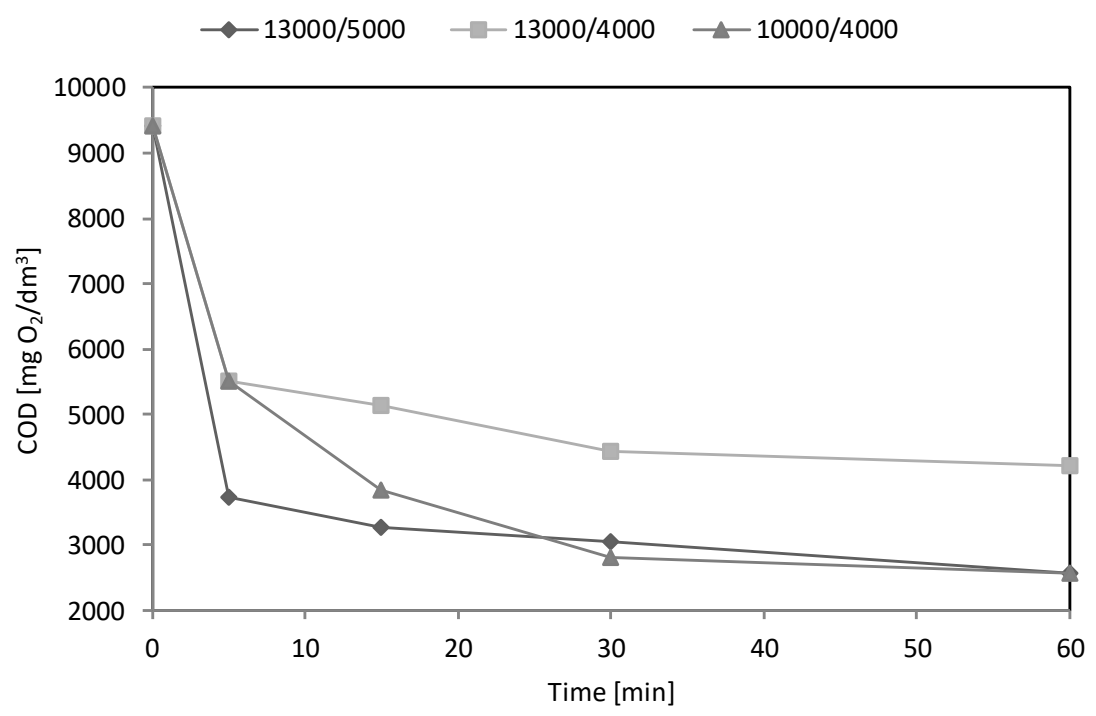

Fig. 2. Time dependence of COD during the Fenton process for sample 3 and $\mathrm{H}_{2} \mathrm{O}_{2} / \mathrm{Fe}^{2+}$ doses $\left(\mathrm{mg} / \mathrm{dm}^{3}\right)$

The values of COD removal are slightly higher than those obtained by Bautista et al. [11], who reached $60.0 \%$. These results were obtained for the $\mathrm{FeCl}_{3}$ pre-coagulated 
wastewater with much lower concentration of organic pollutants (COD $2720 \mathrm{mg} \mathrm{O} / 2 \mathrm{dm}^{3}$ ). The contribution of coagulation was therefore small and the main effect of the process was due to the oxidation reaction.

\section{CONCLUSIONS}

Wastewater from cosmetic plants are susceptible to treatment processes such as coagulation with sedimentation $\mathrm{C} / \mathrm{S}$ and coagulation with dissolved air flotation $\mathrm{C} / \mathrm{DAF}$ based on the neutralization of permanent negative charge of colloids suspended in wastewater. In these two processes, the COD removal obtains is $90 \%$ or higher.

The Fenton process was characterized by a higher efficiency than $\mathrm{C} / \mathrm{S}$ process employing $\mathrm{FeCl}_{3}$ at $\mathrm{pH}$ 9.0. The difference is caused by the two simultaneous treatment processes: chemical oxidation and following coagulation. The difference in the efficiency of the $\mathrm{C} / \mathrm{S}$ and the Fenton processes results from the removal of a part of the contamination by means of chemical oxidation. Upon increasing time, the contribution of oxidation in the Fenton process increases, while the contribution of coagulation decreases.

Cosmetic wastewater produced from soap and shampoo production with high concentration of surfactants can be treated very efficiently using coagulants based on aluminum. Taking into account the economics and process simplicity, coagulation using polymerized, pre-hydrolyzed, aluminum salts seems to be the best solution, reaching COD removal from 82.6 to $91.6 \%$.

\section{ACKNOWLEDGMENTS}

The authors gratefully acknowledge the financial support provided by the National Science Centre (grant no. 7385/B/T02/2011/40 Chemical pretreatment of effluents from cosmetic industry.

\section{REFERENCES}

[1] BUReK M., Report on implemented solutions in the company's wastewater treatment plant AVON Operations Polska, Sp. z o.o., Gaz, Woda, Techn. Sanit., 2008, 12, 31 (in Polish).

[2] ReIF R., SuÁREZ S., OMil F., LEMA J.M., Fate of pharmaceuticals and cosmetic ingredients during the operation of a MBR treating sewage, Desalination, 2008, 221, 511.

[3] Rosal R., Rodriguez A., Perdigon-Melon J.A., Petre A., Garcia-Calvo E., Gomez J.M., Occurrence of emerging pollutants in urban wastewater and their removal through biological treatment followed by ozonation, Water Res., 2010, 44, 578.

[4] El-Gohary F., TAWfiK A., Mahmoud U., Comparative study between chemical coagulation/precipitation $(C / P)$ versus coagulation/dissolved air flotation $(C / D A F)$ for pre-treatment of personal care products (PCPs) wastewater, Desalination, 2010, 252, 106.

[5] Aloui F., KchaOu S., Sayadi S., Physicochemical treatments of anionic surfactants wastewater. Effect on aerobic biodegradability, J. Hazard. Mater., 2009, 164, 353. 
[6] Perdigon-Melon J., Carbajo J., Petre A., Rosal R., Garcia-Calvo E., Coagulation-Fenton coupled treatment for ecotoxicity reduction in highly polluted industrial wastewater, J. Hazard. Mater., 2010, 181, 127.

[7] NAumczyk J., Marcinowski P., Bogacki J., WilińSki P., Treatment of sewage from the cosmetic industry by means of a coagulation process, Rocz. Ochr. Śr., 2013, 15, 875 (in Polish).

[8] NaUmCZYK J., BOGaCKi J., MarcinOwSKi P., Kowalik P., Cosmetic wastewater treatment by coagulation and advanced oxidation processes, Environ. Technol., 2014, 35, 541.

[9] Carpinteyro-Urban S., VaCA M., Torres L.G., Can vegetal biopolymers work as coagulant-flocculant aids in the treatment of high-load cosmetic industrial wastewaters?, Water Air Soil Poll., 2012, 223, 4925.

[10] Boroski M., Rodrigues A.C., Garcia J.C., Sampaio L.C., Nozaki J., Hioka N., Combined electrocoagulation and $\mathrm{TiO}_{2}$ photoassisted treatment applied to wastewater effluents from pharmaceutical and cosmetic industries, J. Hazard. Mater., 2009, 162, 448.

[11] Bautista P., Mohedano A.F., Gilarranz M.A., Casas J., Rodriguez J., Application of Fenton oxidation to cosmetic wastewaters treatment, J. Hazard. Mater., 2007, 143, 128.

[12] Bautista P., Mohedano A., Menendez N., Casas J., Rodriguez J.J., Catalytic wet peroxide oxidation of cosmetic wastewaters with Fe-bearing catalysts, Catal. Today, 2010, 151, 148.

[13] Bautista P., Mohedano A.F., Casas J.A., Zazo J.A., Rodriguez J.J., Oxidation of cosmetic wastewaters with $\mathrm{H}_{2} \mathrm{O}_{2}$ using a Fe/g-Al $\mathrm{O}_{2} \mathrm{O}_{3}$ catalyst, Water Sci. Technol., 2010, 61, 1631.

[14] Carballa M., Manterola G., Larrea L., Ternes T., Omil F., Lema J., Influence of ozone pretreatment on sludge anaerobic digestion. Removal of pharmaceutical and personal care products, Chemosphere, 2007, 67, 1444.

[15] Marcinowski P., Bogacki J., NAUMCZyK J., Cosmetic wastewater treatment using the Fenton, photo-Fenton and $\mathrm{H}_{2} \mathrm{O}_{2} /$ UV processes, J. Environ. Sci. Health A., 2014, 49, 1531.

[16] EBrahiem E.E., Al-Maghrabi M.N., Mobarki A.R., Removal of organic pollutants from industrial wastewater by applying photo-Fenton oxidation technology, Arabian J. Chem., 2013, doi:10.1016/j.arabjc.2013.06.012.

[17] FriHa I., KARRAY F., FeKI F., JLAiell., SAYADI S., Treatment of cosmetic industry wastewater by submerged membrane bioreactor with consideration of microbial community dynamics, Int. Biodeter. Biodegr., 2014, 88, 125.

[18] Monsalvo V.M., Lopez J., Mohedano A.F., Rodriguez J.J., Treatment of cosmetic wastewater by a full-scale membrane bioreactor, Environ. Sci. Pollut., 2014, 21, 12662.

[19] Zhang C., Ning K., Guo Y., Chen J., Liang C., Zhang X., Wang R., Guo L., Cosmetic wastewater treatment by a combined anaerobic/aerobic $(A B R+U B A F)$ biological system, Desal. Water Treat., 2013, $1,1$.

[20] Puyol D., Monsalvo V.M., Mohedano A.F., Sanz J.L., Rodriguez J.J., Cosmetic wastewater treatment by upflow anaerobic sludge blanket reactor, J. Hazard. Mater., 2011, 185, 1059.

[21] Brenntag, www.brenntag.pl (last access on 03.09.2015).

[22] Kemipol, www.kemipol.com (last access on 03.09.2015).

[23] KANG Y.W., HwANG K.-Y., Effects of reaction conditions on the oxidation efficiency in the Fenton process, Water Res., 2000, 34, 2786.

[24] Carballa M., OMil F., Lema J.M., Removal of cosmetic ingredients and pharmaceuticals in sewage primary treatment, Water Res., 2005, 39, 4790.

[25] GumiŃSKa J., KŁos M., Analysis of post-coagulation properties of flocs in terms of coagulant choice, Environ. Prot. Eng., 2012, 38 (1), 103. 